\title{
PENERAPAN MODEL CREATIVE PROBLEM SOLVING BERBASIS BLOG DENGAN IMPLEMENTASI MODEL POE2WE UNTUK MENGHADAPI ABAD 21
}

\author{
Dini Nurpitriani \\ Universitas Siliwangi Tasikmalaya, Jawa Barat, Indonesia \\ Email : dininurpitriani644@gmail.com
}

\begin{abstract}
ABSTRAK : Tujuan dari penulisan ini untuk mendeskripsiskan penerpan model crestiv problem solving berbasis blog dengan implementasi model Poe2we. Model pembelajaran Prediction, Observation, Explanation, Elaboration, Write dan Evaluation (POE2WE) dikembangkan dari model pembelajaran POEW dan model pembelajaran Fisika dengan Pendekatan Konstruktivistik. Model POE2WE merupakan model pembelajaran yang dikembangkan untuk mengetahui pemahaman siswa mengenai suatu konsep dengan pendekatan konstruktivistikuntuk menghadapi abad 21 Komunikasi adalah suatu proses penyam-paian pesan (ide, gagasan) dari satu pihak kepada pihak lain agar terjadi saling rnempengaruhi diantara keduanya. Pada umumnya, komunikasi dilakukan dengan menggunakan kata-ltata (lisan) yang dapat dimengetti oleh kedua belah pihak. Apabila tidak ada bahasaverbal yang dapat dimengerti oleh keduanya, komu-nikasi masih dapat dilakukan dengan menggunakan gerak-gerik badan, menun-jukkan sikap tertentu, misalnya tersenyum, menggelengkan kepala
\end{abstract}

Kata kunci : Blog, Creative Problem Solving, Implementasi Model Poe2we, Menghadapi Abad 21 


\section{PENDAhUluan}

Oktaviani (2015:27) dalam harian detik, 8 Februari 2014, diberitakan bahwa Indonesia menduduki peringkat paling bawah dari 65 negara, dalam pemetaan kemampuan matematika, membaca dan sains. Penilaian tersebut merupakan hasil survei dari Programme for International Student Assessment (PISA) di bawah Organization Economic Cooperation and Development (OECD) pada tahun 2012.

Septiana $(2017: 102)$ guru sebagai pelaksana pendidikan harus menjalankan perannya dalam mewujudkan cita-cita nasional. Untuk menunjang keprofesionalannya, guru mempunyai kewajiban untuk turut serta dalam pelaksanaan inovasi-inovasi pada proses pembelajaran. Inovasi dalam pembelajaran salah satunya dapat dilakukan dengan mengembangkan perangkat pembelajaran yang mengacu pada model pembelajaran tertentu.

Dalam kurikulum 2006, fisika dipandang sebagai mata pelajaran yang dapat mengembangkan kemampuan berpikir sehingga berguna untuk memecahkan masalah dalam kehidupan sehari-hari. Pembelajaran fisika juga diharapkan dapat menumbuhkankemampuan berpikir, bekerja dan bersikap ilmiah, serta berkomunikasi. Sumber daya manusia pada paradigma pendidikan nasional abad 21 harus memiliki beberapa kompetensi, yaitu: (1) kemampuan berpikir kritis dan pemecahan masalah, (2) kemampuan berkomunikasi dan kerjasama, (3) kemampuan mencipta dan membaharui, (4) literasi teknologi informasi dan komunikasi, (5) kemampuan belajar kontekstual, dan (6)kemampuan informasi dan literasi media.

Nana (2018:191) Penyampaian pembelajaran dengan menggunakan teknologi harus memperhatikan berbagai konten yang sesuai dengan batasan umurnya agar tidak terfokus dari inovasi yang digunakan. Namun dalam hal ini, tidak begitu mudah untuk menyebarkan berbagai teknologi yang inovatif di sekolah-sekolah dikarenakan berbagai paham dan sejarah sekolah yang berpengaruh pada pelaksanaanya.

Kegiatn yang dipilih haruslah mendukung kemampuan kognitif yang telah ada pada diri setiap anak sejak usia dini. Hal tersebut akan membuat kemampuan kognitif anak terasah sejak usia dini dan anka tida mendapatkan kesulitan pada jenjang pendidikan yang lebih tingi serta dalam kehidupan ketika dewasa. Salah satu alternative kegiatan yang dapat digunakan untuk meningkatkan kemampan kognitif anak adalah model creative problem solving 
berbasis blog dan kemampuan komunikasi ilmiah

Nana (2018:16) Penilaian autentik merupakan penilaian yang dilakukan secara komprehensif untuk menilai mulai dari masukan (input), proses, dan keluaran (output) pembelajaran, yang meliputi ranah sikap, pengetahuan, dan keterampilan. Penilaian autentik menilai kesiapan siswa, serta proses dan hasil belajar secara utuh. Keterpaduan penilaian ketiga komponen (input -proses-output) tersebut akan menggambarkan kapasitas, gaya, dan hasil belajar peserta didik, bahkan mampu menghasilkan dampak instruksional (instructional effect) dan dampak pengiring (nurturant effect) dari pembelajaran

Fakta empirik yang terkait problematika pembelajaran Sains perlu di kembangkan model dan metode pembelajaran sains yang dapat mencapai ketiga ranah dari Bloom. Salah satu model pembelajaran yang dapat membantu peserta didik untuk mengembangkan sejumlah keterampilan ilmiah atau bekerja ilmiah melalui metode ilmiah sekaligus melatih sikap ilmiah adalah metode saintifik. Dengan metode ini peserta didik dapat mengidentifikasi masalah, menyusun hipotesis, memprediksi konsekuensi hipotesis, melakukan eksperimen untuk menguji hipotesa, dan merumuskan hukum umum yang sederhana yang di organisasikan dari hipotesis, prediksi dan eksperimen. Dalam metode eksperimen tidak hanya aspek kognitif saja, melainkan aspek psikomotorik dan afektif bisa di amati oleh guru.

\section{METODE PENELITIAN}

Metode yang digunakan dalam artikel ini adalah studi literature atau pustaka. Data dikumpulkan dan dianalisis kemudian disajikan dalam hasil dan pembahasan agar dapat dibuat kesimpulan.

\section{HASIL PEMELITIAN DAN PEMBAHASAN}

\section{A. Pengertian dan Sintaks Model Pembelajaran POE2WE}

Model pembelajaran Prediction, Observation, Explanation, Elaboration, Write dan Evaluation (POE2WE) dikembangkan dari model pembelajaran POEW dan model pembelajaran Fisika dengan Pendekatan Konstruktivistik. Model POE2WE merupakan model pembelajaran yang dikembangkan untuk mengetahui pemahaman siswa mengenai suatu konsep dengan pendekatan konstruktivistik. Model ini membangaun pengetahuan dengan urutan proses terlebih dahulu meramalkan atau memprediksi solusi dari 
permasalahan, melakukan eksperimen untuk membuktikan prediksi, kemudian menjelaskan hasil eksperimen yang diperoleh secara lisan maupun tertulis, membuat contoh penerapan dalam kehidupan sehari-hari, menuliskan hasil diskusi dan membuat evaluasi tentang pemahaman siswa baik secara lisan maupun tertulis.

Model pembelajaran POE2WE dapat menjadikan siswa sebagai subjek di dalam pembelajaran. Siswa aktif dalam menemukan suatu konsep melalui pengamatan atau eksperimen secara langsung, bukan dari menghafal buku materi maupun penjelasan dari guru. Model ini memungkinkan siswa aktif dalam proses pembelajaran, memberikan kesempatan kepada siswa untuk mengkonstrukssi pengetahuannya, mengkomunikasikan pemikirannya dan menuliskan hasil diskusinya sehingga siswa lebih menguasai dan memahami konsep yang akan berdampak pada peningkatan prestasi belajar siswa. Hal tersebut sesuai dengan pendapat Permatasari (2011:1) bahma model ini memberikan kesempatan kepada siswa untuk mengkonstruksi pengetahuannya sendiri, melakukan pengamatan terhadap fenomena serta mengkomunikasikan pemikiran dan hasil diskusi sehingga siswa akan lebih mudah menguasai konsep yang di ajarkan.

Penggabungan tahapan-tahapan pem belajaran model POEW dan model pembelajaran Fisika dengan Pendekatan Konstruktivistik maka dapat di susun langkah- langkah pembelajaran model POE2WE secara terinci sebagai berikut:

a. Prediction

Tahap prediction yaitu siswa membuat prediksi atau dugaan awal terhadap suatu permasalahan. Permasalahan yang ditemukan berasala dari pertanyaan dan gambar tentang gerak lurus oleh guru yang ada di LKS/buku siswa sebelum siswa membuat prediksi. Pembuatan prediksi jawaban tahap Prediction pada model POEW identik dengan fase Engagenent pada pendekatan konstruktivistik. Guru mengajukan pertanyaan yang dapat mendorong siswa untuk dapat membuat prediksi atau jawaban sementara dari suatu permasalahan.

b. Observation

Tahap Observation yaitu untuk membuktikan prediksi yang telah di buat oleh siswa. Siswa diajak melakukan eksperimen berkaitan dengan masalah atau persoalan yang di temukan. Selanjutnya siswa mengamati apa yang terjadi, kemudian siswa menguji kebenaran dari dugaan sementara yang telah dibuat. Tahap Observation pada 
model POEW identik dengan fase Exploration pada pendekatan konstruktivistik.

c. Explanation

Tahap Explanation atau menjelaskan yaitu siswa memberikan penjelasan terhadap hasil eksperimen yang telah dilakukan. Penjelasan dari siswa dilakukan melalui diskusi dengan anggota kelompok kemudian tiap kelompokn mempresentasikan hasil diskusinya di depan kelas. Jika prediksi yang di buat siswa ternyata terjadi di dalam eksperimen, maka guru membimbing siswa merangkum dan memberi penjelasan untuk menguatkan hasil eksperimen yang dilakukan. Namun jika prediksi siswa tidak terjadi dalam eksperimen, maka guru membantu siswa mencari penjelasan mengapa prediksi atau dugaannya tidak benar. Tahap explanation identik dengan fase explanation pada pendekatan konstuktivistik.

\section{d. Elaboration}

Tahap elaboration yaitu siswa membuat contoh atau menerapkan konsep dalam kehidupan sehari-hari. Tahap elaboration di ambil dari pendekatan konstruktivistik. Tahap ini guru medorong siswa untuk menerapkan konsep baru dalam situasi baru sehingga siswa lebih memahami konsep yang di ajarkan guru. Tahap ini pengembangan dari pendekatan konstruktivistik.

e. Write

Tahap write atau menulis yaitu melakukan komunikasi secara tertulis,merefleksikan pengetahuan dan gagasan yang dimiliki siswa. Menurut Masingilia dan Wisniowska (1996) dalam Ansari (2012) menulis dapat membantu siswa untuk mengekspresikan pengetahuan dan gagasan mereka. Siswa menuliskan hasil diskusi dan menjawab pertanyaan yang ada pada LKS. Selain itu pada tahap write ini, siswa membuat kesimpulan dan laporan dari hasil eksperimen. Tahap ini merupakan pengembangan dari model TTW.

\section{f. Evaluation}

Tahap Evaluationyaitu evaluasi terhadap pengetahuan, keterampilan dan perubahan proses berfikir siswa. Pada tahap ini siswa di evaluasi tentang materi gerak lurus berupa lisan maupun tulisan.Tahap ini merupakan pengembangan dari pendekatan konstruktivistik. Penggabungan tahap-tahap model POEW dan pendekatan konstruktivistik 


\section{B. Creative Problem Solving}

Model pembelajaran sebagai upaya untuk meningkatkan keberhasilan belajar siswa. Penerapan model dapat disesuaikan dengan kemampuan, sarana dan prasarana yang berkaitan dengan proses pemecahan masalah (Valqui Vidal, 2010: 408). Pemecahan masalah yang membutuhkan kreativitas dengan mendefinisikan berbagai pertanyaan untuk diselesaikan dan dicari solusinya. Penting sekali dalam memahami struktur masalah dengan berbagai pemikiran kreatif. Proses pemecahan masalah melibatkan pengalaman baru yang secara logis di susun dengan sistematis. Masalah juga perlu dilihat dan diketahui kebenarannya (Ridong $\mathrm{Hu}$ et al, 2017: 3140-3141). Langkah-langkah dalam model creative problem solving antara lain sebagai berikut; proses pemecahan masalah dengan kreatif dengan menyeleksi informasi baru, masalah yang telah diindentifikasi kemudian di konsep secara komprehensif, proses masalah yang telah di konsep untuk menemukan solusi dari masalah yang nyata (Basadur el al, 2014: 83).

\section{Blog}

Menurut Boyd (dalam Nana 2018: 192)Istilah blog memiliki definisi yang berbeda-beda dari setiap penelitinya dikarenakan perbedaan definisi secara struktural. Selain itu, blog diartikan sebagai komunikasi internet yang digunakan untuk memberi informasi lewat media sosial. Blog berisi fitur-fitur berupa informasi yang berbasis teknologi baik motivasi yang dideskripsikan. Penggunaan blog pada intinya berkaitan dengan pengetahuan yang menjadikan penggunanya untuk menganalisis berbagai informasi yang berbeda-beda dari pemblog. Di sisi lain, pembuat informasi lewat blog yaitu blogger dengan tujuan untuk memberi informasi bagi pengguna blog. Blog juga dianggap sebagai komunitas yang mengikat bloger-bloger lain untuk berkarya dalam media internet (Silva, 2016: 83).

\section{Penerapan Model Creative Problem Solving Berbasis Blog Dengan Implementasi Model POE2EW Untuk Menghadapi Abad 21}

Salah satu masalah dalam proses pengajaran di sekolah yaitu bagaimana mengembangkan keterampilan siswa agar menjadi kreatif dan sesuai dengan bakatnya. Setiap siswa dilatih sesuai dengan keterampilan dan bakat yang dimiliki agar dapat meningkatkan motivasi. Keterampilan yang harus dimiliki oleh siswa berkaitan dengan 
penalaran verbal-numerik, pemikiran secara abstrak, mengingat informasi sesuai dengan keabsahan data (Cetinkaya, 2014: 3722-3723). Pengembangan keterampilan siswa dapat melalui berbagai inovasi dalam pembelajaran yaitu dengan menggunakan model yang tepat dan sesuai dengan karakteristik siswa. Salah satu model yang sesuai dengan daya kreatif siswa yaitu dengan creative problem solving.

Motley dalam Prasetyo (2014) ber-pendapat bahwa komunikasi adalah transmisi informasi, baik bersifat verbal maupun non-verbal. Berbagai perspektif definisi proses komunikasi inilah yang akan mengantarkan pada pendekatan komunikasi ilmiah yang lebih banyak ter-jadi dalam dimensi riset, inquiry, dan in-vensi dari para ilmuwan (researcher). Sebagai mahluk sosial manusia ha-rus dapat berkomunikasi dengan manusia lainnya. Dalam blognya dicky umbara (2007) mengatakan bahwa:

Komunikasi adalah suatu proses penyam-paian pesan (ide, gagasan) dari satu pihak kepada pihak lain agar terjadi saling rnempengaruhi diantara keduanya. Pada umumnya, komunikasi dilakukan dengan menggunakan kata-ltata (lisan) yang dapat dimengetti oleh kedua belah pihak. Apabila tidak ada bahasaverbal yang dapat dimengerti oleh keduanya, komu-nikasi masih dapat dilakukan dengan menggunakan gerak-gerik badan, menun-jukkan sikap tertentu, misalnya tersenyum, menggelengkan kepala.

Komunikasi anak dengan guru menunjang produktifitas anak dalam meningkatkan kreatifitas anak, dengan media kominikasi digital menjadi terobosan untuk merangsang anak agar lebih interaktif dan menarik dalam pembelajaran. Guru hanya menjadi sumber belajar bagi anak sehingga potensi anak bisa keluar dan dapat di pantau perkembangannya. Permatasari (2011:1) bahma model ini memberikan kesempatan kepada siswa untuk mengkonstruksi pengetahuannya sendiri, melakukan pengamatan terhadap fenomena serta mengkomunikasikan pemikiran dan hasil diskusi sehingga siswa akan lebih mudah menguasai konsep yang di ajarkan.

\section{PENUTUP}

Dari berbagai pembahasan yang telah dijabarkan dapat ditarik kesimpulan dan dimaknai bahwa model pembelajaran yang berbasis masalah secara kreatif dapat meningkatkan motivasi siswa agar lebih terpacu dalam keberhasilan belajarnya. Kesesuaian keterampilan dan bakat siswa dapat berpengaruh pada hasil yang dicapai sehingga perlunya keprofesionalan guru sebagai pengajar agar dapat menjadikan siswa menjadi lebih kreatif 
dengan media internet yaitu penggunaan blog.

Dalam peroses pembelajarannya anak bisa terkontrol dengan baik oleh guru, sebab segala yang dilakukan anak guru sudah mengetahui perkembangan anak lewat beberapa metode, sehingga output dari siswa bisa terlihat dengan jelas dan sisiwa dalam pembelajarannya bisa mengoktimalkan kemampuan anak agar dikemudian hari anak bisa terbisa belajar mandiri dan guru mempunyai pengawasan dengan oktimal dan kemudahan dunia digital menjadi sumber agar pembelajaran menjadi mudah, menarik dan cepat mengerti.

\section{UCAPAN TERIMA KASIH}

Terima kasih kepada semua pihak yang telah membantu demi kesempurnaan artikel ini menjadii lebih baik kepada Bapak Dr. Nana, M.Pd. selaku dosen pengampu Fisika Sekolah II atas bimbingannya.

\section{DAFTAR PUSTAKA}

Oktaviani. (2015). Penerapan Model Creative Problem Solving Pada Pembelajaran Kalor Untuk Meningkatkan Pemahaman Konsep dan Keterampilan Komunikasi unes 27-31

Nana. (2018). Penerapan Model Creative Problem Solving Berbasis Blog Sebagai Inovasi Pembelajaran Di Sekolah Menengah Atas Dalam Pembelajaran Fisika. Seminar Nasional Fisika dan Aplikasinya 190-195

Septiana Wijayanti. (2017). Pengembangan Perangkat Pembelajaran Mengacu Model Creative Problem Solving Berbasis Somatic, Auditory, Visualization, intellectually 101-110

Nana. (2018). Implementasi Model POE2WE Dengan Pendekatan Saintifik Dalam Pembelajaran Gerak Lurus di SMA 15-28 
